\title{
ГЛИБИННА ПСИХОКОРЕКЦІЯ ЯК ЗАСІБ ФАХОВОЇ САМОРЕАЛІЗАЦІЇ ПСИХОЛОГА-ПРАКТИКА
}

\author{
УДК:378.06:159.98-051
}

\section{Бугерко Ярослава Миколаӥвна}

\begin{abstract}
Кандидат психологічних наук, доцент, дочент кафедри психологї та сочіальної роботи

Тернопільського начіонального економічного університету, м. Тернопіль (Украӥна)
\end{abstract}

\begin{abstract}
Анотація. У статті розглядаються особливості професійної підготовки психологапрактика. Аналізується метод активного сочіально-психологічного пізнання (АСПП) як психокорекиійна практика глибинного спрямування. Виділено та охарактеризовано аспекти глибинно-психологічного пізнання психіки людини в процесі діагностико-корекційної роботи психолога: спонтанна активність респондента як необхідна умова вияву дисфункцій його психіки; емотивне ожсилення як показник діагностичної спроможності запитань психолога; імовірнісне прогнозування як засіб вияву логічної впорядкованості психіки; духовний розвиток як результат покрокових змін в напрямі гармонізаџії і врівноваження свідомої і несвідомої сфер психіки людини. Показано, щзо поступальні зміни учасників психокорекційної групи розширюють горизонти їх самосвідомості завдяки пізнанню системних характеристик власної психіки, мінімізації викривлень, які є вимушеними під натиском імперативу несвідомого.
\end{abstract}

Ключові слова: глибинна психокорекція, метод активного соціальнопсихологічного пізнання (АСПП), логічна впорядкованість психіки, професійна психологічна підготовка.

Постановка проблеми. Інтеграція національної освіти в європейський освітній простір ставить нові вимоги щодо підготовки конкурентоздатного фахівця з високим рівнем професіоналізму, здатного до особистісного самовдосконалення та професійного саморозвитку. Вимоги до компетентності, поведінки, культури, наявності необхідних професійно важливих якостей у фахівців-практиків і, відповідно, до рівня їх професійної та особистіс- ної підготовки в системі вищих навчальних закладів 3 кожним роком зростають і це цілком закономірно, оскільки саме від загальноособистісного розвитку залежать результати і наслідки професійної діяльності майбутніх фахівців.

Зазначене особливо важливе в професії майбутнього психолога. Психологічна практика - особлива галузь знань, у якій без належного формування особистісних характеристик 
та корекції деструктивних проявів особистості неможлива фахова майстерність. Значні можливості в реалізації зазначеного містить глибинна психокорекція, зокрема метод активного соціально-психологічного пізнання (АСПП), розроблений акад. Т. С. Яценко. Проходження студентами глибинної корекції дає імпульс їх прагненням до особистісних змін, оволодіння навичками професійнопізнавального проникнення в глибини психіки, дозволяє намітити шляхи нівелювання деструктивних утворень, породжених негараздами минулого досвіду.

Аналіз останніх досліджень і публікацій. Питання професійної підготовки психологів-практиків, підвищення рівня їх кваліфікації одержало широке відображення у працях відомих українських вчених (дослідження Ж. П. Вірної, С. Д. Максименка, В. Г. Панка, О. П. Саннікової, В. А. Семиченко, Т. М. Титаренко, Н. Ф. Шевченко, Н. В. Чепелєвої, Ю. М. Швалба, А. В. Фурмана, Т. С. Яценко та ін.). Кожна авторська концепція розкриває певні важливі аспекти проблеми та намічає шляхи іiї вирішення. Розгляду проблем фахового самовизначення та професійної диференціації психологічного товариства, розмежуванню наукових та практичних видів психологічної діяльності присвячені праці В. І. Подшивалкіної [5]. Аналіз взаємовідношень між психологічною наукою і психологічною практикою як стосунків між рухом- поступом психологічного пізнання і життямдіяльністю психолога здійснив П. А. Мясоїд [3]. Узагальнення науково-методичних матеріалів та досвіду організації психологічної служби в Україні, виділення основних підходів до змісту і методів професійної підготовки практичних психологів проведені В. Г. Панком [4]. Вітакультурне обгрунтування практичної психології як сфери науководосвідної роботи, певного способу світорозуміння і самозреалізування, за якого психологпрактик не лише вивчає людину, мислить, проектує і взаємодіє з нею, а й залучає їі до певного способу буття і світобачення, вивільняючи у такий спосіб горизонти для внутрішньої свободи, психологічного здоров'я та духовного зростання представлені в напрацюваннях А. В. Фурмана [7]. Широкого поширення набула психокорекційна практика глибинного спрямування Т. С. Яценко, яка передбачає цілісне бачення психіки людини в системних взаємозв'язках свідомої і несвідомої сфер та синтезі теоретичних парадигм, сформованих у процесі психологічної практики. Адекватним методом психодинамічного підходу $\epsilon$ активне соціально-психологічне пізнання (АСПП), в якому зінтегровані глибинно-психологічні знання, що сприяють особистісній психокорекції учасників навчання та підвищують ефективність підготовки психологів-практиків [9-12].

В низці досліджень (О. Ф. Бондаренко, Н. І. Пов’якель, О. П. Саннікова, 
Н. В. Чепелєва, Т. С. Яценко) вказується на необхідність проходження майбутніми практичними психологами психотерапевтичних сесій у ролі клієнта вже під час навчання у вузі, що дозволить їм усвідомити свої захисні реакції, побачити типові форми поведінки у ситуаціях, що актуалізують їх власні проблеми, розвинути здатність відстежувати свої проек-ції, рефлексувати їх і відповідно коригувати взаємодію з іншими.

Водночас недостатньо уваги приділено таким важливим в підготовці майбутнього психолога-практика аспектам, як узгодженість теоретико-методологічного базису глибинного пізнання 3 інструментальнометодичним його забезпеченням, створення оптимальної моделі діагностико-корекційної, аналітико-діалогічної роботи психолога 3 респондентом. Тому метою статті $є$ розкрити особливості використання АСПП як практико -зорієнтованого методу глибиннопсихологічного пізнання психіки людини в процесі діагностико-корекційної роботи психолога.

Виклад основного матеріалу досліджсеня. Концепція розвитку вищої освіти в Україні містить принципову спрямованість на перехід до нового типу гуманістичної освіти, в якій зростають самодостатність, самостійність, самосвідомість суб'єктів освітнього процесу. Зростає усвідомлення важливості оволодіння випускниками не лише технологічними особливостями професійної діяльності, а й їх власне особистісне зростання, розвиток їх духовно-емоційної сфери. Особливо важлива особистісна відкорегованість та високий рівень духовності в професійній діяльності майбутнього психолога.

Водночас констатуємо, що на підготовку фахівців зазначеного профілю вплинуло домінування протягом тривалого часу в радянській психології діяльнісного підходу та недооцінка глибинних детермінант розвитку психодуховної сфери особистості. Спрощене розуміння мотивів поведінки особистості, вплив ідеології, абсолютизування свідомості як вищого рівня регулювання характеру діяльності на основі прийнятих людиною цінностей і моральних норм, не врахування наявності несвідомої інстанції психіки з ії функціональним багатством, власною автономією та взаємозв'язками зі свідомим характеризували той етап розвитку психологічної науки у 80-ті роки минулого століття, коли зароджувалась нова галузь - практична психологія. Поза увагою більшості дослідників залишалося несвідоме як внутрішній феномен, котрий не вписувався у зовнішньо задану категорію психічного, так само як і поняття немотивованих вчинків, ірраціональних дій, інфантильних та регресивних виявів поведінки.

Стрімкий розвиток психологічної служби того часу та відсутність фахівців глибинно-психологічного спрямування в $\dddot{11}$ кадровому складі спричинив орієнтування в основному на тестові дослідження, яким 
характерна фронтальність та усереднення отриманих даних замість глибинного пізнання унікального внутрішнього світу Я кожної окре-мої людини. В значній мірі цьому сприяла відсутність грунтовних досліджень академічною психологією феномену несвідомого, а відтак і належним чином не досліджувалися глибин-но-психологічні детермінанти психодуховної сфери особистості. Водночас слід зазначити, що грунтовне вивчення несвідомої сфери психіки людини проводилось окремими науковцями, що засвідчують наукові матеріали Міжнародного конгресу в Тбілісі, викладені в чотирьохтомнику «Несвідоме». Щоправда зазначені дослідження були мало пристосовані для їх прикладного застосування. Психологічна практика 3 необхідністю передбачає вивчення цілісного феномену психіки, врахування складних і нелінійних взаємозв'язків свідомої і несвідомої сфер. Розвиток тогочасної прикладної психології, зокрема психологічної служби характеризувався дискретнофункціональним підходом до вивчення психіки людини. Основний акцент здійснювався на діагностиці і обмежувався стандартизованими методиками, тестами, що апелюють до свідомих аспектів психіки. Значно менше уваги було приділено корекційній роботі, особливо в іï глибинно-психологічному спрямуванні. В середовищі практикуючих психологів була відчутна потреба застосування таких оптимальних методик групових форм роботи, які б забезпечували як діагностичний, так i глибинно-психокорекційний вплив та сприяли психодуховному розвитку особистості [2].

В цьому плані варто відмітити метод активного соціально-психологічного пізнання (АСПП), розроблений академіком НАПН України Т.Яценко. Виникнувши як метод активного соціально-психологічного навчання, 3 часом він не лише набув глибиннопсихологічної орієнтації в плані психокорекції, але і відкрив можливості наукового дослідження психіки у взаємозв'язках іiі свідомих і несвідомих проявів [9-12]. Метод АСПП опирається на психодинамічну методологію і розглядає психіку як цілісне системне утворення, що дозволяє розкрити її внутрішню динамічну сутність, від розуміння якої залежить прогнозування поведінки суб'єкта.

Вже $з$ початку свого створення зазначений метод психокорекції містив орієнтацію на практично-педагогічні аспекти підготовки особистості до процесу ефективного спілкування і активно використовувався 3 прикладною метою [1]. 3 90-х років метод набув яскраво вираженого психоаналітичного зорієнтування. А сама методика, завдяки діалогічній взаємодії та психоаналітичним інтерпретаціям, уможливила виокремлення логіки несвідомого у контексті цілісного дослідження психіки, iii усистематизованих спрямувань, котрі продукуються несвідомою сферою. Створена 
Т. С. Яценко модель внутрішньої динаміки психіки [12, с. 38$]$ засвідчила складність категорії психічного та багатоаспектність взаємозв'язків між суперечливими за своєю сутністю підструктурами. Авторка зазначала, що вузькоплановий та фрагментарний погляди на психічне, орієнтація тільки на раціональні аспекти і нехтування ірраціональними, алогічними проявами у психологічній практиці є неприйнятними.

Зазначена модель дозволяє професійним психологам усвідомити, що «алогічне» (ірраціональне) є таким лише з погляду оцінювання свідомого розуму. Однак якщо виходити 3 цілісного сприйняття психічного, то ірраціональні явища - це наслідок дії «іншої логіки», якій вони підпорядковані і яка $€$ не менш чіткою, ніж логіка свідомого, до того ж енергетично більш потужна, перебуває поза часом і простором. Таке розуміння робить пізнання психічного цілісним, адекватним та дозволяє уникнути спрощеного сприйняття цього феномена, його однобічного тлумачення $з$ позиції категорії «свідоме». Саме тому у процесі професійної підготовки майбутніх психологів до практичної роботи з психокорекції модель внутрішньої динаміки психіки слугує «ниткою Аріадни» у складних лабіринтах розуміння та пізнання цілісної психіки людської особистості [11].

Психодинамічний підхід в пізнанні психічного зорієнтований на його цілісність. Це потребує не тільки розкриття функційних особливостей несвідомого, але і розробки інструментальних аспектів реставрування втрачених (порушених) взаємозв'язків із свідомістю. Особливості глибинно-психологічного пізнання психіки людини в процесі діагностико-корекційної роботи психолога розглянемо у відповідності з юнгіанським принципом кватерності. Для цього використаємо розроблений проф. А.В. Фурманом один із засобів методологування - мислесхему [8]. Графічно вона відображає одержане знання у вигляді квадрата, що поміщений у коло, а певне розташування стрілок вказує напрямок руху або мислеформу думки (рис. 1).

$$
\text { Метод активного соціально- }
$$
психологічного пізнання передбачає використання феноменологічного підходу, який проявляється у підвищеній увазі до індивідуальної неповторності феномену психічного і до його актуалізації в ситуації спонтанної мимовільної поведінки. Саме забезпечення спонтанності і мимовільності поведінки є початком професійного підходу до глибинного пізнання. «Професійно важливим завданням є створення умов, які сприяють прояву мимовільної поведінки, без будь-яких зовнішньо обумовлених викривлень, що виключає авторитарність вказівок «що робити». Цим метод АСПП суттєво відрізняється від інших практик, зорієнтованих на регламентованість поведінки» [9, c. 115]. Під час застосування методу глибинної психокорекції відбувається робота із спонтанними моделями поведінки членів групи, 


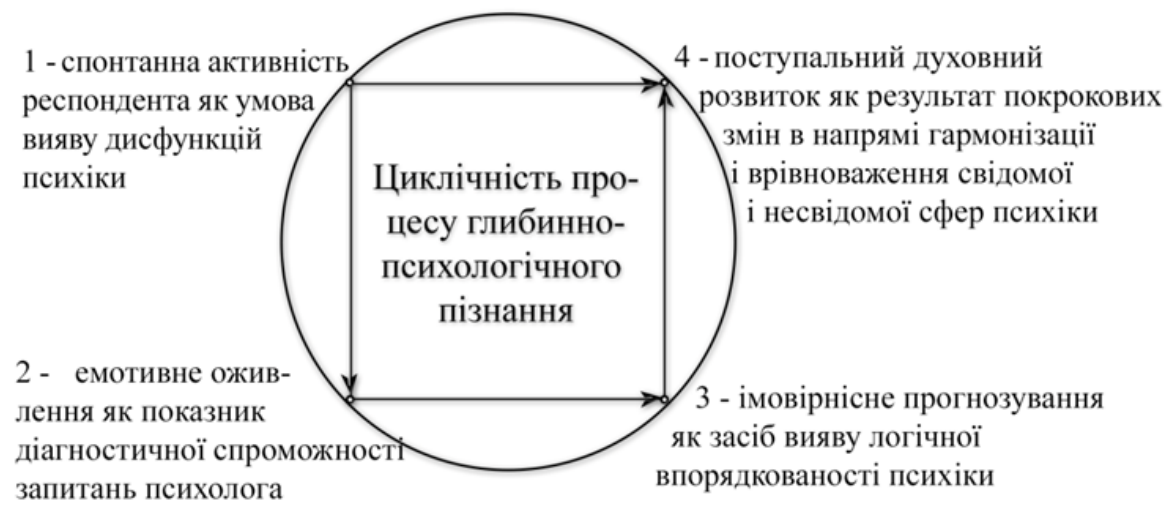

\section{Рис. 1. Особливості глибинно-психологічного пізнання психіки людини в процесі діагнос- тико-корекційної роботи психолога}

котрі відтворюють значимий та фіксований зміст індивідуальної психіки, який протягом життя пройшов систему витіснення та обробки механізмами перенесення, заміщення, зміщення та згущення. Чим більш наявною та активною у групі АСПП є міжособистісна взаємодія учасників навчання з притаманними їй характеристиками спонтанності та невимушеності, тим більшою є імовірність та об'єктивна можливість глибинно-психологічного пізнання.

А тому важливим є створення в групі АСПП умов, які б не активізували ситуативні форми захисту. Цьому сприяє введення принципів щирості, прийняття учасників такими, якими вони $\epsilon$, відсутність критики, оцінних суджень, рекомендацій, заохочень, покарань тощо. Вищезазначене знімає потребу і, відповідно, активність особи в утвердженні власних гідностей Я, що виявляються за низкою просоціальних параметрів. Натомість відкриваються умови для презентації внутрішніх (неусвідомлюваних) детермінант завдяки декларуванню і втіленню в динаміку групових цінностей спонтанності та невимушеності поведінки особи, що надає пріоритетності її внутрішнім спонукам до активності [9].

Виникає питання, де містяться витоки ініціативності учасників групового процесу активного соціально-психологічного пізнання, за умови, що базовою методичною засадою його організації $\epsilon$ спонтанність та невимушеність поведінки учасників. Авторка методу вказує на важливість такого чинника людської активності як інтерес до самопізнання. Саме цей мотив $є$ визначальним для формування психокорекційної групи АСПП за умов практичної дії принципу добровільності. Водночас, слід враховувати і наявність особистісного опору, який виникає під час самопізнавальних дій, а тому важливою є підтримка активності суб'єкта, що можливе лише в ситуаціях розширення простору реалізації можливос- 
тей самопізнання та пізнання психіки іншого всіма учасниками психокорекційної групи. Іншими словами, мовиться про актуалізацію важливих для психопізнавального процесу передумов рефлексії, розвитку сензитивності, емпатії та вміння узагальнювати все те, що сприймається, відчувається та емоційно переживається в групі. До низки цих передумов можна щонайперше віднести становлення в АСПП групових норм, які забезпечують психологічну захищеність кожного учасника навчання і створюють робоче настановлення на пізнання в системі «людина-людина» у ситуації «тут і тепер». Виникає ситуація «очі в очі» (при розташуванні в коло), коли активність одного члена групи породжує ініціативу іншого, актуалізує різнорівневі процеси наслідування-творення. В такий спосіб психокорекційна група АСПП - суцільний ланцюг динамічно-мінливих очікувань ii учасників, який залежить від групової динаміки і ступеня внутрішнього проникнення, є взаємопізнавальною стихією «усіх і кожного» $[10]$.

Характерною для роботи групи активного соціально-психологічного пізнання $\epsilon$ така ситуація, за якої усі їі члени працюють лише $з$ тим матеріалом, який чули, бачили, відчували, емоційно сприймали та переживали. Однак це є необхідна, але не достатня умова для одержання кінцевого психокорекційного результату. Емоція в груповій ситуації АСП - першоджерельне віконце, крізь яке проходить промінь світла у несвідоме і піднімає «на поверхню свідомості» пев-ний зміст, котрий $€$ індикатором семантики несвідомого як складової сфери психіки людини [11]. «Енергія емоційних переживань має тенденцію до переходу із внутрішнього плану в зовнішній. При цьому задіюються внутрішні енергетичні стимули «задоволення - незадоволення». Задоволення потягів узгоджується з принципом задоволення i приводить до розслаблення (зниження напруження енергіi), тоді як незадоволення зберігає енергетичний потенціал пробудження до активності і тенденцію до повтору (задання) дії. Об'єктивація несвідомого в глибинному пізнанні супроводжується оживленням ефектів, пов'язаний, в основному 3 драматичним досвідом пережитих людиною емоційних незадоволень, травм і напруг [11, c. 27].

Сучасні психологічні дослідження (Знаков В. В.,1990) вказують на те, що аналіз духовних станів людини нерозривно пов'язаний 3 пошуками коренів духовності в нерефлексованих глибинах несвідомого Я людини. За висловом В. Франкла «людська духовність не просто неусвідомлена, а неминуче несвідома. Дух не рефлексує сам себе, оскільки самоспостереження, яке намагається схопити його в його зародженні, в його джерелі, засліплює його» [6, с. 96]. Це є причиною пояснення, чому проблеми внутрішнього плану є настільки складними і важко- 
вирішуваними. Людина здатна усвідомлювати лише зовнішні їх прояви, в поле її зору не потрапляють фактори глибиннопсихологічного порядку, пов'язані з неусвідомлюваними чи витісненими імпульсами Ід. Попри неусвідомлюваність, їхня діяльність не лише не зникає. Глибиннопсихологічні інтереси-цінності користуються будь-якими можливостями своєї реалізації, посилюючи енергетичний ракурс периферійних захистів і таким чином розширюючи можливості реалізації глибиннопсихологічного (інфантильного) інтересу.

Емпіричний матеріал, отриманий у групі АСПП, видається цінним лише тією мірою, коли дає змогу виявити, об'єктивувати засобами узагальнення його логічну впорядкованість. Хаос у несвідомому існує тільки на рівні такої підструктури особистості, якою $€$ «Ід». Вивчення психіки у процесі глибинної психокорекції стосуються тих рівнів та структурних компонентів психіки, які віднесяться до категорії передсвідомого [10, с.165]. Одна 3 функцій передсвідомого - вербалізація неусвідомлюваного змісту, в т. ч. і спонукань «Ід». Така вербалізація несвідомого від-бувається за умов виникнення конфлікту між підструктурами особистості «Супер-Его», «Его», «Ід». Тому психологічне пізнання несвідомого завжди пов'язане із виникненням суперечностей у поведінці, а вже через них можна фіксувати внутрішній конфлікт суб'єкта [там же].

Діагностико-корекційна майстерність психолога дозволяє об'єктивувати протиріччя в спрямованостях свідомої і несвідомої сфер психіки людини і цим сприяє їх усвідомленню особистістю. Зазначене збільшує енергетичну потентність свідомості і попереджує внутрішньо невиправдане спалювання енергії «в ножицях» протидії протистоянню протилежно спрямованих тенденцій свідомого і несвідомого.

Проблема результативності діагностико-психокорекційної діяльності, як зазначає Т. С. Яценко, пов'язана із імовірнісною логікою організації практичного пошуку [10, с. 167]. Перевірка ступеня імовірності істини передбачає фіксацію переходу від висловлювання до самої події. Імовірнісний чинник відіграє вагому роль у групах АСПП, тому що гіпотези переважно стосуються прогнозів впливу різних механізмів несвідомого на актуальну поведінку суб'єкта. До того ж ці гіпотези здебільшого не повідомляються психологом членам групи, хоч і впливають на структурування ним динаміки групового процесу, що, зі свого боку, каталізує поведінку учасників такого навчання та створює умови для верифікації гіпотез [там же].

Аналіз логічної впорядкованості поведінкового матеріалу учасників навчання психолог здійснює 3 допомогою імовірнісного прогнозування. Це сприяє виявленню асиметричних розходжень в енергетичній спрямованості двох сфер психіки, які про- 
являють себе в «логіці свідомості» і «логіці несвідомого». А тому обов'язковою умовою професійного становлення психолога $€$ оволодіння ним інструментарієм пізнання імовірнісної логіки, котра включає проміжні істинні значення, базові для прогнозів в їх подальшому підтвердженні. При цьому відбувається перехід від мови прогнозів (під впливом висловлювань респондента) до їх підтвердження шляхом розкриття впорядкованості (логічності) поведінкового матеріалу, одержаного в діалогічній взаємодії [11, с. 11].

Специфіка глибинного пізнання полягає у неможливості абсолютного пізнання через наявність фактора неповної достовірності. Окрім того, імовірнісна логіка не обмежується двозначністю: «істина - неістина», а є полізначною. Виникає парадоксальна ситуація в процесі глибинного пізнання, коли імовірність істини наштовхується на невизначеність змісту спонтанної поведінки. Зазначене долається засобом порційості і багаторівневості вивчення латентносмислового навантаження мимовільної поведінки, яка каталізується діалогічною взаємодією психолога 3 респондентом (при вбудуванні питань в імплікативний порядок психіки). Таким чином одержується можливість впливати на мотивацію реінтеграції психіки учасника навчання під впливом неминучої логіки емпіричного фактажу. Імовірнісне прогнозування, як основа глибин- ного пізнання, «сприяє розкриттю внутрішньої заданості активності психічного, яка прокладає шлях до формування порядку через терни випадковостей і варіативності його символізації. Конкретизація (індивідуалізація) сказаного відбувається в самому процесі АСПП шляхом визначення логічної впорядкованості психіки, яка виявляється в інтерпретації асоціативних взаємозв'язків, які характерні спонтанній поведінці суб'єкта. Це - шлях від символічної багатозначності до знаковості. При таких умовах випадковість вчинків зменшується за рахунок вияву їх логічної впорядкованості, що відкриває перспективи пізнання глибинних першопричин» [11, с. 13].

Діагностика, яка здійснюється у єдності з процесом психокорекції в групі АCПП, має багаторівневий характер, а тому передбачає багатоступінчатість психокорекційних висновків, їх порційність та узгодженість із перспективами глибиннопсихологічного пізнання і самокорекції учасників групового навчан-ня. Такі поступальні покрокові зміни учасників психокорекційної групи розширюють горизонти їх самосвідомості завдяки пізнанню системних характеристик власної психіки, мінімізації викривлень, які є вимушеними під натиском імперативу несвідомого. Пізнаючи власну інфантильну залежність, людина відмежовує себе від небезпеки повторення пережитого травматичного досвіду минулого, 
який може задаватися законом «вимушеного повторення», а усвідомлення асиметричної спрямованості свідомої та несвідомої сфер психіки пробуджує інстинкт соціального самозбереження і розширює можливості власного потенціалу особистості [9].

Групи АСПП можна назвати групами особистісного зростання, оскільки в їх учасників відкриваються канали для нової особистісно значимої інформації, яку іншим способом, ніж через об'єктивування несвідомих факторів, через рефлексивне пропрацювання матеріалу, неможливо пізнати. Завдяки єдності діагностичного і корекційного процесу в учасників навчання відбувається не лише усвідомлене розуміння поведінкових проявів та певних якостей своєї особистості, але й прийняття їх через розуміння глибинно-інфантильних витоків. Це, своєю чергою, сприяє розвитку таких духовних проявів особистості як мужність і чесність у сприйнятті часто неочікуваної інформації про себе, толерантність, позитивне сприйняття і розуміння іншої людини (завдяки розумінню дії механізмів захистів). При цьому розвивається рефлексивність та соціально-перцептивний інтелект, розширюється свобода поведінки за рахунок реалістичності вчинків і нівелювання ідеалізованості Я, яке тяготіло до ілюзорних способів утвердження власних гідностей. В таких психокорекційних групах глибинного спрямування людина розвиває мудрість, що дозволяє розуміти цілісність психіки в єдності іiі діаметрально протилежних тенденцій поведінки. Водночас відбувається зниження тенденції «до слабкості», пов'язаної з почуттям неповноцінності, страхом неспроможності керувати власною поведінкою, боязню імпульсивності. Розширення самосвідомості учасників навчання дозволяє їм більш адекватно прогнозувати результати взаємодії, посилює просоціальну орієнтацію поведінки людини, розширює можливості пізнання системних характеристик несвідомого в їх логічній впорядкованості і дозволяє нівелювати енергетичну різноспрямованість двох сфер психіки [10].

Важливою передумовою повноцінної підготовки майбутнього психолога виступає єдність теорії та практики. А тому формування професіоналізму психологапрактика не можливе без оволодіння ним методологією, яка інтегрує поряд 3 теоретичними знаннями, інструментальнометодичні аспекти діагностико-корекційної роботи. Цьому сприяють принципи організації АСПП. Для майбутнього психолога важливо навчитися перетворювати себе в об’єкт дослідження, бути в ситуації і бути над нею, децентрувати увагу та набути багато інших практичних вмінь. Відмітимо, що особливістю такого досвідноекспериментального типу навчання, який здійснюється в групах АСПП є те, що керівник виступає помічником, фасилітатором, він не наповняє семантикою поведінковий 
матеріал, а лише допомагає виявити його смисл і спрямованість енергії, за якою криються тенденції поведінки. Саме останні заслуговують на особливу увагу, оскільки допомагають виявити логіку мимовільної активності суб'єкта як на рівні свідомості, так і на рівні несвідомого. Розширення самосвідомості учасників навчання дозволяє їм здійснювати вибір оптимальних форм поведінки і більш адекватно прогнозувати результати своєї життєдіяльності.

Висновки і перспективи подальщих розвідок

\section{у даному напрямі}

$\Rightarrow$ Період навчання у вузі - найбільш сприятливий для формування професійноважливих якостей майбутнього фахівця, викристалізуванння індивідуальних особистісних якостей молодої людини. Психологічна практика - особлива галузь знань, у якій без належного формування особистісних характеристик та корекції деструктивних проявів особистості неможлива фахова майстерність. Проходження студентами глибинної корекції дає імпульс їх прагненням до особистісних змін, оволодіння навичками професійно-пізнавального проникнення в глибини психіки як своєї, так і іншої людини, дозволяє намітити шляхи нівелювання деструктивних утворень, породжених негараздами минулого досвіду, особливо раннього дитинства.

$\Rightarrow$ Метод активного соціально-психологічного пізнання (АСПП), як психокорекційна практика глибинного спрямування передбачає цілісне бачення психіки людини в системних взаємозв'язках свідомої і несвідомої сфер. Він охоплює той аспект професійної підготовки, який випадає з поля уваги академічно-зорієнтованих програмних курсів, спрямованих на засвоєння стандартних (класичних) знань і органічно вбудовується в загальну програму вузівської підготовки психологів до діагностико-корекційної практичної роботи, розширюючи горизонти ïх особистісного зростання, сприяючи розвитку рефлексивного інтелекту та духовного потенціалу особистості психологапрактика.

$\Rightarrow$ Діагностика, яка здійснюється у єдності 3 процесом психокорекції в групі АСПП, має багаторівневий характер, а тому передбачає багатоступінчатість психокорекційних висновків, їх порційність та узгодженість із перспективами глибиннопсихологічного пізнання і самокорекції учасників групового навчан-ня. Такі поступальні покрокові зміни учасників психокорекційної групи розширюють горизонти їх самосвідомості завдяки пізнанню системних характеристик власної психіки, мінімізації викривлень, які $\epsilon$ вимушеними під натиском імперативу несвідомого.

$\Rightarrow$ Подальшого дослідження потребує вивчення специфіки глибинного пізнання, що відбувається в самому процесі АСПП шляхом визначення логічної впорядкованості 
психіки завдяки імовірнісному прогнозуванню, аналізу архетипної символіки, поступальному духовному розвитку учасників навчання.

\section{Перелік використаних джерел:}

1. Аврамченко C., Сергієнко I. Розвиток вітчизняної практичної психології у науковій школі Тамари Яценко / Світлана Аврамченко, Ірина Сергієнко // Психологія і суспільство. - 2005. - № 2. - С. 5-17.

2. Бугерко Я. М. Глибинно-психологічні аспекти духовності особистості / Я. М. Бугерко // Актуальні проблеми психології: Зб. наукових праць Інституту психології імені Г.С.Костюка НАПН України. 2016. - Том. IX: Загальна психологія. Історична психологія. Етнічна психологія. - Випуск 9. - С.92-99.

3. М'ясоїд П. Наука і практика у роботі психолога / Петро М’ясоїд // Психологія і суспільство. - 2004. - № 3. - C. 5-74.

4. Панок В. Професійне становлення практичних психологів: досвід і перспективи / Віталій Панок // Психологія і суспільство. - 2013. - № 3 . - С. 135-141.

5. Подшивалкіна В. Проблеми фахового самовизначення та професійної диференціації психологічного товариства / Валентина Подшивалкіна // Психологія і суспільство. -2005 . - № 1 . - С. 7-15.

6. Франкл В. Человек в поисках смысла / В. Франкл. М. : Прогресс, 1990. - 368 с.

7. Фурман А. В. Вітакультурне обгрунтування практичної психології / А. В. Фурман // Практична психологія і соціальна робота. - 2003. - № 4(51) . - С. 23-27.

8. Фурман А. В. Ідея і зміст професійного методологування : [монографія] / Анатолій Васильович Фурман . Тернопіль : ТНЕУ, 2016. $-378 \mathrm{c}$.

9. Яценко T. С. Концептуальні засади і методика глибинної психокорекції: Підготовка психолога-практика: Навч. посібник / Т. С. Яценко, Б. Б. Іваненко, С.М. Аврамченко та ін.; за ред. Т. С. Яценко. - К. : Вища шко- ла, 2008. -342 с.

10. Яценко $\quad$ T. $C$. Метод активного соціальнопсихологічного навчання: індуктивно-дедуктивне обгрунтування / Тамара Яценко // Психологія і суспільство. - 2001. - № 1. - С. 164-173.

11. Яценко T. C. Методология глубиннокоррекционной подготовки психолога / Т. С. Яценко, A. В. Глузман. - Днепропетровск : Изд-во «Инновация», 2015. - $396 \mathrm{c.}$

12. Яиенко $T$. Теоретико-методологічний підхід до цілісного розуміння психіки у ії структурних компонентах / Тамара Яценко // Психологія і суспільство. 2004. - № 4. - C. 37-59.

\section{References (Transliteration):}

1. Avramchenko S., SergIEnko I. Rozvitok vItchiznyanoYi praktichnoYi psihologIYi u naukovly shkolI Tamari Yatsenko / SvItlana Avramchenko, Irina SergIEnko // PsihologIya I suspIlstvo. - 2005. - \# 2. - S. 5-17.

2.Bugerko Ya. M. Glibinno-psihologIchnI aspekti duhovnostI osobistostI / Ya. M. Bugerko // AktualnI problemi psihologIYi: Zb. naukovih prats Institutu psihologIYi ImenI G.S.Kostyuka NAPN UkraYini. - 2016. - Tom. IH: Zagalna psihologIya. Istorichna psihologIya. EtnIchna psihologIya. - Vipusk 9. - S.92-99.

3. M'yasoYid P. Nauka I praktika u robotI psihologa / Petro M'yasoYid // PsihologIya I suspIlstvo. - 2004. - \# 3 . - S. 5-74.

4. Panok $V$. ProfesIyne stanovlennya praktichnih psihologIv: dosvId I perspektivi / VItally Panok // PsihologIya I suspIlstvo. - 2013. - \# 3 . - S. 135-141.

5. Podshivalkina $V$. Problemi fahovogo samoviznachennya ta profesIynoYi diferentsIatsIYi psihologIchnogo tovaristva / Valentina PodshivalkIna // PsihologIya I suspIlstvo. - 2005. - \# 1 . - S. 7-15.

6. Frankl V. Chelovek v poiskah smyisla / V. Frankl. - M. : Progress, 1990. $-368 \mathrm{~s}$.

7. Furman A.V. VItakulturne obGruntuvannya praktichnoYi psihologIYi / A. V. Furman // Praktichna psihologIya 
I sotsIalna robota. $-2003 .-\# 4(51)$. - S. 23-27.

8. Furman A. V. Ideya I zmIst profesIynogo metodologuvannya : [monograflya] / Anatolly Vasilovich Furman . - TernopIl : TNEU, 2016. - 378 s.

9. Yatsenko T. S. KontseptualnI zasadi I metodika glibinnoYi psihokorektsIYi: PIdgotovka psihologa-praktika: Navch. posIbnik / T. S. Yatsenko, B. B. Ivanenko, S.M. Avramchenko ta In.; za red. T. S. Yatsenko. - K. : Vischa shkola, 2008. - $342 \mathrm{~s}$.

10. Yatsenko T. S. Metod aktivnogo sotsIalnopsihologIchnogo navchannya: Induktivno-deduktivne obGruntuvannya / Tamara Yatsenko // PsihologIya I suspIlstvo. - 2001. - \# 1. - S. 164-173.

11. Yatsenko T. S. Metodologiya glubinno-korrektsionnoy podgotovki psihologa / T. S. Yatsenko, A. V. Gluzman. Dnepropetrovsk : Izd-vo «Innovatsiya», 2015. - 396 s.

12. Yatsenko T. Teoretiko-metodologIchniy pIdhId do tsIIIsnogo rozumInnya psihIki u YiYi strukturnih komponentah / Tamara Yatsenko // PsihologIya I suspIlstvo. - 2004. \# 4. - S. 37-59.

\section{Buherko Yaroslava}

Candidate of Psychological Sciences, Docent, Associate Professor at the Department of Psychology and Social Work at Ternopil National Economic University, Ternopil (Ukraine)

\section{DEEP PSYCHOCORRECTION AS WAY OF PRACTICAL PSYCHOLOGIST PROFESSIONAL SELF-FULFILLMENT}

\section{ABSTRACT}

In article features of practical psychologist's professional education are considered by deep psychocorrection tools. It is shown that forming practical psychologist's professionalism is impossible if he do not master by methodology that integrates theoretical knowledge with instrumental methodological aspects of diagnostic cor- rectional work. A method of the active sociopsychological cognition (ACPC) is analyzed as deep direction psychocorrection practice. Received results show that diagnostics, which is made in tandem with the process of psychocorrection in the ACPC group, has multilevel nature, and therefore psychocorrectional conclusions should also be multilevel and conform to group education members' perspectives of the deep psychological cognition and self-correction.

A detailed analysis of such specific feature of the deep cognition as probabilistic logic of practical search organization has been presented. A probabilistic forecasting contains intermediate true values that consist basis for forecasting the influence of different unconscious mechanisms on the subject actual behavior, and get confirmation by considering the orderliness (logic) of behavioral material that was received in dialogical interaction between psychologist and respondent.

The next aspects are characterized of deep -psychological cognition of human mentality in psychologist's diagnostic-correctional work: spontaneous activity of respondent as condition of revealing of his psychics dysfunctions; emotional revival as an indicator of psychologist's diagnostic capability; probabilistic forecasting as a tool of detection of logical ordered psychics; progressive spiritual development as a result of changes step by step to harmonization of human psychics conscious and unconscious spheres. It is demonstrated that progressive changes step by step extend the self-identity of psychocorrectional 
group members due to cognition of own psychics system characteristics, minimization of curvatures that are forced under the unconscious imperative press.

Author has proved that learning by student deep psychological knowledge in ACPC process promotes to their personal psychocorrection, and improve the efficiency of the training of psychologists-practitioners.

Keywords: deep psychocorrection, method of the active socio-psychological cognition (ACPC), psychics logical ordering, professional psychological education.

\section{Бугерко Ярослава Николаевна}

Кандидат психологических наук, доиент, дочент кафедры психологии и социальной работь Тернопольского национального экономического университета, г. Тернополь (Украина)

\section{ГЛУБИННАЯ ПСИХОКОРРЕКЦІЯЯ КАК СРЕДСТВО ПРОФЕССИОНАЛЬНОЙ САМОРЕАЛИЗАЦИИ ПСИХОЛОГА- ПРАКТИКА}

Аннотация. В статье рассматриваются особенности профессиональной подготовки психолога-практика. Анализируется метод активного социально-психологического познания (АСПП) как психокоррекционная практика глубинного направления. Выделены и охарактеризованы аспекты глубиннопсихологического познания психики человека в процессе диагностико-коррекционной работы психолога: спонтанная активность респондента как необходимое условие проявления дисфункций его психики; эмотивное оживление как показатель диагностической точности вопросов психолога; вероятностное прогнозирование как средство выявления логической упорядоченности психики; духовное развитие как результат пошаговых изменений в направлении гармонизации и уравновешивания сознательной и бессознательной сфер психики человека. Показано, что поступательные изменения участников психокоррекционной группы расширяют горизонты их самосознания благодаря познанию системных характеристик собственной психики, минимизации искажений, которые являются вынужденными под натиском бессознательного императива.

Ключевые слова: глубинная психокоррекция, метод активного социальнопсихологического познания (АСПП), логическая упорядоченность психики, профессиональная психологическая подготовка. 